\title{
Newer drugs for the treatment of hepatitis B viral infection
}

Sir,

One of the main disadvantages of hepatitis $\mathrm{B}$ virus treatment is the persistence of the virus even after treatment. The main causes of this viral persistence can be an inadequacy of the immune function as well as some viral factors. The currently available drugs for hepatitis B are five oral nucleoside/nucleotide analogs (lamivudine, adefovir dipivoxil, tenofovir, entecavir, telbivudine) and two interferon drugs (interferon alfa-2b, pegylated interferon alfa-2a). However, these therapies do not lead to sustained remission, requiring indefinite treatment as viral load frequently rebounds once suppressive therapy is stopped. ${ }^{1}$ This is mainly because current therapy is ineffective in clearing cccDNA or preventing transcriptional cccDNA activity. ${ }^{2}$ Another disadvantage is the need for indefinite treatment with nucleoside analogues. Due to these drawbacks, several researches are being conducted in this field and so many newer targets are being discovered. Besifovir is a new nucleoside/nucleotide analogue with therapeutic efficacy similar to Tenofovir. In Phase IIa clinical study, LB80380 was found to be effective in reducing the viral load in lamivudine resistant $\mathrm{HBeAg}$-positive $\mathrm{CHB}$ patients for a period of 12 weeks. ${ }^{3}$ The treatment with besifovir was found safe and effective for $\mathrm{CHB}$, both treatment naive cases as well as others. The only problem found was the depletion of L-carnitine, which was easily rectified with a carnitine supplement. ${ }^{1}$ Painter et al report that, in vitro, the hexadecyloxypropyl ester of tenofovir, CMX157, is 267-fold more active than tenofovir against HIV-1 and 4.5 fold more active against $\mathrm{HBV} .{ }^{4} \mathrm{~A}$ multiple ascending dose phase II study was completed with CMX157 in 2017. Myrcludex B and vanitaracin A target the viral sodium taurocholate cotransporting polypeptide (NTCP). Myrcludex-B not only prevented the spread of HBV from infected human hepatocytes in vivo; but also hindered amplification of the cccDNA pool in initially infected hepatocytes. ${ }^{3}$ Phase II randomized open label multicentric clinical trial of daily myrcludex $\mathrm{B}$ with entecavir in $\mathrm{HBeAg}$ negative CHB was completed in 2014. Kaneko et $\mathrm{al}^{5}$ identified vanitaracin $\mathrm{A}$ as a fungal metabolite which was a potent, safe, and broadly active inhibitor of HBV \& HDV entry. cccDNA transcription can be targeted by zinc finger nucleases and transcription activator like effector nucleases (TALENs). Viral vectors for expressing in vivo zinc finger nucleases are in the pipeline. CRISPR/CAS9 is another effective method that targets cccDNA and offers hope of a complete cure. These therapies are not yet in clinical development. The induction of APOBEC3 group of cytidine deaminases is another mechanism by which cccDNA could be disrupted by genetic editing.
Viral assembly is an important step in the lifecycle of hepatitis B virus and a critical target of drug action. Heteroaryldihydropyrimidines are highly potent nonnucleosidic inhibitors of HBV replication. Among them, BAY 41-4109, which was studied in a phase I clinical trial, was found to misdirect the HBV capsid assembly and interfere with the viral infection. ${ }^{6}$ Novira recently completed a phase Ia clinical trial with a new capsid assembly effector (NVR 3-778, later acquired by Johnson \& Johnson), and revealed that combinations with entecavir (ETV) or pegIFN had additive and/or synergistic antiviral activity leading to high viral load suppression efficacy in infected humanized mouse models. ${ }^{6}$

Glucosidase inhibitors suppress viral infectivity and morphogenesis, likely by inhibition of the glycosylation of the envelope protein in endoplasmic reticulum. ${ }^{1}$ Celgosvir is a glucosidase inhibitor who has given encouraging phase IIa data.

Table 1: List of drugs in pipeline for hepatitis $B .{ }^{11}$

\begin{tabular}{|c|c|c|}
\hline Drug name & $\begin{array}{l}\text { Mechanism of } \\
\text { action }\end{array}$ & $\begin{array}{l}\text { Current } \\
\text { status }\end{array}$ \\
\hline Besifovir & Nucleotide analogue & Phase II \\
\hline CMX157 & Nucleotide analogue & Phase II \\
\hline $\begin{array}{l}\text { Lagociclovir } \\
\text { valactate }\end{array}$ & Nucleotide analogue & Discontinued \\
\hline Myrcludex B & Entry inhibitor & $\begin{array}{l}\text { Phase II } \\
\text { completed }\end{array}$ \\
\hline GC1102 & Entry inhibitor & Phase II \\
\hline ABI-H0731 & $\begin{array}{l}\text { Core protein } \\
\text { inhibitor }\end{array}$ & Phase II \\
\hline BAY 41-4109 & $\begin{array}{l}\text { Viral capsid } \\
\text { assembly inhibitor }\end{array}$ & Phase I \\
\hline NVR-3778 & $\begin{array}{l}\text { Viral capsid } \\
\text { assembly inhibitor }\end{array}$ & $\begin{array}{l}\text { Progressed } \\
\text { to Phase II }\end{array}$ \\
\hline JNJ56136379 & $\begin{array}{l}\text { Viral capsid } \\
\text { assembly inhibitor }\end{array}$ & Phase II \\
\hline Celgosvir & $\begin{array}{l}\text { Glucosidase } \\
\text { Inhibitor }\end{array}$ & Discontinued \\
\hline Vesatolimod & TLR 7 Agonist & Phase II \\
\hline Selgantolimod & TLR 8 Agonist & Phase II \\
\hline $\begin{array}{l}\text { Inarigravir } \\
\text { sopraxil }\end{array}$ & Immunomodulator & Phase II \\
\hline HLX 10 & Immunomodulator & $\begin{array}{l}\text { Recruiting in } \\
\text { Phase II }\end{array}$ \\
\hline $\begin{array}{l}\text { Recombivax, } \\
\text { Sci-b-Vac, } \\
\text { HepavaxGene }\end{array}$ & $\begin{array}{l}\text { Therapeutic } \\
\text { Vaccines }\end{array}$ & $\begin{array}{l}\text { In clinical } \\
\text { trials }\end{array}$ \\
\hline
\end{tabular}


Nucleic acid polymers have both entry and postentry antiviral activity. They enter infected hepatocytes and interfere with some aspect of SVP assembly or trafficking through an acidified compartment in the secretory pathway which prevents the release of small virion particles into the circulation. ${ }^{7}$ A different approach is being taken by Spring Bank, which is developing inarigivir (SB9200), an orally administered linear dinucleotide, as an RIG-I (retinoic acid inducible gene) agonist with the objective of activating cellular innate immune responses in $\mathrm{HBV}$ infected cells. ${ }^{8}$ Antisense oligonucleotides, ribozymes, and RNA interference can be used to directly target viral mRNA. ${ }^{1}$ An RNAi based drug currently in clinical trials is ARC-520, a dynamic polyconjugate in which the RNAi trigger is conjugated to cholesterol, which is coinjected with a hepatocyte targeted, membrane active peptide. ${ }^{9}$

Augmenting the innate immune response may aid in reconstitution of $\mathrm{HBV}$ specific immunity by enhancing intrahepatic innate immunity and priming effective adaptive anti HBV immunity. ${ }^{1}$ Activation of toll like receptors can lead to increased innate immunity and thereby holds the power of inhibiting DNA replication of the virus. Vesatolimod, TLR 7 agonist and selgantolimod, TLR 8 agonist are now in clinical trials. Interferons are induced by the use of TLR agonists together with nucleoside analogues, and this provides immunity against hepatitis B infection. IL-7 and IL-21 are cytokines with immunomodulatory properties that can be utilized in chronic hepatitis B. Thymus gland is the source of thymosin alpha 1, which has immunomodulating property. NOV-205 is another immune booster with hepatoprotective properties. Guo et al said that treatment of immortalized mouse hepatocytes supporting HBV replication with either cGAMP or a small molecule pharmacologic STING (stimulator of interferon genes) agonist significantly reduced viral DNA in a STING and Janus kinase 1 dependent manner. ${ }^{10}$ Therapeutic vaccination is a method to boost $\mathrm{HBV}$-specific immunity which includes immunogenic complex vaccines, tarmogens (targeted molecular immunogen), adenovirus based therapeutic vaccination, and DNA vaccines.

Thus, pharmacotherapy of hepatitis B is an area with vast research opportunities and newer target molecules are being identified fast which will hopefully make the treatment easier and more effective.

\section{Sreelakshmi Venugopal ${ }^{1 *}$, Dhanya Thirookaran Harichandran ${ }^{1}$, K. B. Sanalkumar ${ }^{2}$, M. B. Sujatha ${ }^{1}$}

\footnotetext{
${ }^{1}$ Department of Pharmacology, Government Medical College, Thrissur, Kerala, India

${ }^{2}$ Department of Pharmacology, Government Medical College, Manjeri, Kerala, India
}

*Correspondence to

Dr. Sreelakshmi Venugopal, E-mail: sreelakshmivenugopal123@gmail.com

\section{REFERENCES}

1. Ward H, Tang L, Poonia B, Kottilil S. Treatment of hepatitis B virus: an update. Future Microbiol. 2016;11(12):1581-97.

2. Durantel D, Zoulim F. New antiviral targets for innovative treatment concepts for hepatitis B virus and hepatitis delta virus. Journal of hepatology. 2016;64(1):S117-31.

3. Wang XY, Chen HS. Emerging antivirals for the treatment of hepatitis B. World journal of gastroenterology. 2014;20(24):7707.

4. Painter GR, Almond MR, Trost LC, Lampert BM, Neyts J, De Clercq E, et al. Evaluation of hexadecyloxypropyl-9-R-[2-(Phosphonomethoxy) propyl]-adenine, CMX157, as a potential treatment for human immunodeficiency virus type 1 and hepatitis B virus infections. Antimicrobial agents and chemotherapy. 2007;51(10):3505-9.

5. Kaneko M, Watashi K, Kamisuki S, Matsunaga H, Iwamoto M, Kawai F, et al. A novel tricyclic polyketide, vanitaracin A, specifically inhibits the entry of hepatitis B and D viruses by targeting sodium taurocholate cotransporting polypeptide. Journal of virology. 2015;89(23):11945-53.

6. Boucle S, Lu X, Bassit L, Ozturk T, Russell OO, Amblard F, et al. Synthesis and antiviral evaluation of novel heteroarylpyrimidines analogs as $\mathrm{HBV}$ capsid effectors. Bioorganic \& medicinal chemistry letters. 2017;27(4):904-10.

7. Vaillant A. Nucleic acid polymers: broad spectrum antiviral activity, antiviral mechanisms and optimization for the treatment of hepatitis B and hepatitis D infection. Antiviral research. 2016;133:32-40.

8. Lopatin U. Drugs in the pipeline for HBV. Clinics in liver disease. 2019;23(3):535-55.

9. Gish RG, Yuen MF, Chan HLY, Given BD, Lai CL, Locarnini SA, et al. Synthetic RNAi triggers and their use in chronic hepatitis B therapies with curative intent. Antiviral Res. 2015;121:97-108.

10. Guo F, Tang L, Shu S, Sehgal M, Sheraz M, Liu B, et al. Activation of stimulator of interferon genes in hepatocytes suppresses the replication of hepatitis B virus. Antimicrobial agents and chemotherapy. 2017; 61(10):e00771-17.

11. U. S. National Library of Medicine. ClinicalTrials.gov. Available at: https://clinicaltrials.gov/ct2/results?cond=\%22Hepati tis+B\%22. Accessed 9 September 2020.

Cite this article as: Venugopal S, Harichandran DT, Sanalkumar KB, Sujatha MB. Newer drugs for treatment of hepatitis B viral infection. Int J Basic Clin Pharmacol 2020;9:1625-6. 